Article

\title{
Occurrence of BVDV Infection and the Presence of Potential Risk Factors in Dairy Cattle Herds in Poland
}

\author{
Krzysztof Rypuła ${ }^{1, *}$, Katarzyna Płoneczka-Janeczko ${ }^{1}$, Michał Czopowicz ${ }^{2}$, \\ Malgorzata D. Klimowicz-Bodys ${ }^{1}$, Sergey Shabunin ${ }^{3}$ and Georges Siegwalt ${ }^{4}$ \\ 1 Division of Infectious Diseases of Animals and Veterinary Administration, Department of Epizootiology and \\ Clinic of Birds and Exotic Animals, Faculty of Veterinary Medicine, Wroclaw University of Environmental \\ and Life Sciences, pl. Grunwaldzki 45, 50-366 Wroclaw, Poland; \\ katarzyna.ploneczka-janeczko@upwr.edu.pl (K.P.-J.); malgorzata.klimowicz-bodys@upwr.edu.pl (M.D.K.-B.) \\ 2 Division of Veterinary Epidemiology and Economics, Institute of Veterinary Medicine, \\ Warsaw University of Life Sciences, Nowoursynowska Street 159c, 02-776 Warsaw, Poland; \\ mczopowicz@gmail.com \\ 3 All-Russian Veterinary Research Institute of Pathology, Pharmacology and Therapy, Lomonosova Street 114 \\ b, 394087 Voronezh, Russia; main@vsau.ru \\ 4 Boehringer Ingelheim RCV GmbH \& Co KG, Animal Health, Dr. Boehringer-Gasse 5-11, 1121 Wien, Austria; \\ georges.siegwalt@boehringer-ingelheim.com \\ * Correspondence: krzysztof.rypula@upwr.edu.pl; Tel.: +48-71-3205-326
}

Received: 8 January 2020; Accepted: 27 January 2020; Published: 31 January 2020

check for updates

Simple Summary: The bovine viral diarrhea virus (BVDV) causes one of the most common and economically important viral diseases of cattle. It affected cattle reproductive disorders in breeding cattle as well as decreased productivity through increased forced culling, morbidity, and mortality, all of which can be observed on the herd level. The aim of our study was the estimation of the occurrence of BVDV infection in different regions of Poland and the analysis of the different factors that could be correlated with the productive results. We evaluated 354 cattle herds. The presence of antibodies against the BVD virus was found in $33.3 \%$ of examined herds, and the heterogenous distribution of BVDV-positive herds in all regions of Poland was confirmed. We found that the rate of BVDV infection was strongly correlated with the geographical location of the examined cattle populations in Poland, the grazing of the animals, and the purchasing of new animals to be introduced to herds.

Abstract: The aim of the study was to analyze the risk factors of BVDV infection, in different regions of Poland, with respect to certain parameters of animal health, including productivity, herd management practices, the presence of BVDV, and the effect of non-vaccination. A total of 354 cattle herds were estimated and linked to the analysis of the different factors that might be correlated with productive results. The presence of antibodies against BVDV was found in $33.3 \%$ of examined herds, and the heterogenous distribution of BVDV-positive herds in all regions of Poland $(p=0.001)$ was confirmed. We found statistical correlations between BVDV infection and pasture $(p=0.004)$ and the number of grazing animals $(p<0.001)$, and also the purchase of animals for replacement $(p=0.004)$ was observed. Production or clear clinical outcomes potentially linked to BVDV infection in the herd have not been observed. The results of this study indicate that the rate of BVDV infection was most strongly correlated with the geographical location of the examined cattle populations in Poland. The second most significant factors were the grazing of animals and the purchasing of new animals to be introduced to herds. The strengthened procedures of management, as well as the implementation of eradication programs, should be considered in the examined herds.

Keywords: BVDV; dairy cattle; risk factors 


\section{Introduction}

The bovine viral diarrhea virus (BVDV) is a small single-stranded positive-sense RNA virus, classified in the genus Pestivirus within the Flaviviridae family [1]. Two species, BVDV-1 and BVDV-2, are discriminated on the basis of genetic and antigenic differences. The International Committee on Taxonomy of Viruses (ICTV) recognizes four main separate species that are members of the Pestivirus genus: BVDV- 1, BVDV-2, border disease virus (BDV), and classical swine fever virus (CSFV) [2]. Moreover, a growing number of tentative Pestivirus species isolated from domestic and wild ruminant species and from pigs, ("Giraffe", "Pronghorn" or "Bungowannah" viruses) [3-5] as well as atypical (Th/04_KhonKaen, HoBi-like, and CH-KaHo/cont) Pestivirus species, has been identified and described [6-9].

This virus causes one of the most common and economically important viral diseases of cattle. It affects industrialized cattle farming systems by inducing reproductive disorders (abortion, overdue birth - prolonged gestation, reduced fertility) in breeding cattle and by reducing herd productivity through increased forced culling, morbidity, and mortality [10,11].

The principal source of infection is a persistently infected (PI) animal. Healthy, immunocompetent adult cattle and calves tend to suffer from acute BVDV infections, causing seroconversion that occurs 2-3 weeks after infection, leading to lifelong immunity. The ability of BVDV to cross the placenta and fetal infection during early pregnancy can result in the birth of PI calves [12,13]. Yet, transiently infected animals (TI) are considered to be of minor importance in the spread of the disease [13]. However, BVDV due to TI animals might circulate within a herd for a prolonged period, even in the absence of PIs [14]. Most control programs consist of the identification and elimination of PI animals (removing the source of infection TI animals) based on this pathogenesis [15]. The aim of this study was to analyze the risk factors of BVDV infection in different regions of Poland with respect to certain parameters of animal health, including productivity, herd management practices, the presence of BVDV, and the effect of non-vaccination.

\section{Materials and Methods}

\subsection{Sample Collection}

Samples were collected from cattle herds where the routine laboratory milk tests have been performed to estimate the current status of the targeted infectious diseases. In total, BTM (bulk tank milk) samples were collected at 354 dairy farms from five regions of Poland between January 2015 and May 2016. These five geographical regions included: Central (C), consisting of Mazovia and Łódź Voivodships; Southern (S), consisting of Lower Silesia, Opole, Silesia, and Lesser Poland Voivodships; North-Western (N-W), consisting of Greater Poland, Lubsz, and West-Pomerania Voivodship; Northern $(\mathrm{N})$, consisting of Warmia-Masuria, Kuyavia-Pomerania, and Pomerania Voivodships; Eastern (E), consisting of Holy Cross Province, Subcarpathia, Lublin, Podlaskie Voivodships (Figure 1). These regions were designated according to the Chief of Statistical Office, taking into account the number of cows per 100 ha of agricultural area [16]. Thus, we investigated: (C) 41 herds, (S) 59 herds, $(\mathrm{N}-\mathrm{W}) 98$ herds, (N) 93 herds, and (E) 63 herds. The concentration of cows per 100 ha of the agricultural area in the selected regions were: (C) Mazovia-25.5 and Łodz-17.8; (S) Lower Silesia-4.4, Opole-8.6, Silesia-11.9, and Lesser Poland-13.5; (N-W) Greater Poland-15.7, Lubsz-7.7 and West-Pomerania-4.7; (N) Warmia-Masuria-22.0, Kuyavia-Pomerania-14.5 and Pomerania-9.3; (E)—Holy Cross Province-11.2, Subcarpathia-11.2, Lublin—9.7, and Podlaskie-41.9. None of the cattle in any of the farms had been vaccinated against BVDV over the preceding year, and no other special criteria were included when selecting the farms. 


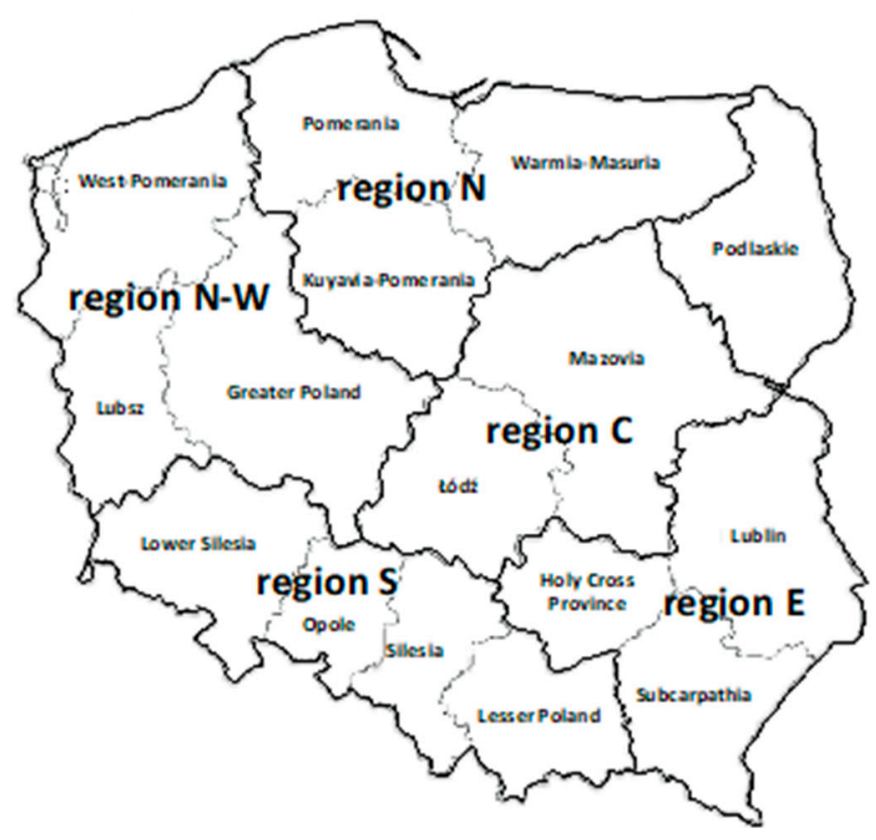

Figure 1. Examined geographical regions of Poland according to the Chief Statistical Office with modification, including the concentration of cows per 100 ha of the agricultural area.

BTM samples were collected into $100 \mathrm{ml}$ containers with no preservatives. The containers were labelled in detail by appointed veterinarians. Collected samples were transported directly to the Diagnostic Laboratory EPI-VET, the Faculty of Veterinary Medicine, and Wroclaw, which implements a quality management system (ISO/IEC 17025:2005 + API:2007 + AC:2007). All samples were transported to the laboratory at $4-8{ }^{\circ} \mathrm{C}$ within $24 \mathrm{~h}$ after collection. BTM samples were centrifuged at $1000 \times \mathrm{g}$ for $15 \mathrm{~min}$ at $4{ }^{\circ} \mathrm{C}$. Fat was skimmed off and finally the supernatant was collected. Centrifugation was repeated twice to ensure this. Then, the supernatant was stored in $1 \mathrm{~mL}$ aliquots at $-20{ }^{\circ} \mathrm{C}$, until analysis.

\subsection{ELISA Test}

To investigate and detect antibodies of NS-3 BVDV an indirect ELISA test was used (Bio-X Diagnostics, Rocheford, Belgium). The obtained results were expressed as S/P. The relative amount of antibodies was calculated using the positive control as a reference, according to the manufacturer's instructions. The relationship is expressed as a s/p ratio (Sample to Positive Ratio).

val $\leq 20 \%=0$ negative;

$20 \%<\mathrm{val} \leq 40 \%=(+)$;

$40 \%<\mathrm{val} \leq 60 \%=(++)$;

$60 \%<\mathrm{val} \leq 80 \%=(+++)$;

$80 \%<\mathrm{val} \leq 100 \%=(++++)$;

$100 \%<\mathrm{val}=(+++++)$.

A sample was considered positive if the obtained result was greater than or equal to one plus $(+)$.

\subsection{Questionnaire}

To analyze how BVDV infection affects production in cattle, veterinarians who worked at the selected farms (with the cooperation of the animal owners) were asked to complete questionnaires. The questionnaires contained general and specific information, including: the total number of animals in the herd, the number of animals in lactation, the average age at first calving, the average calving interval, milk yield/production, and access to the pasture of particular age groups. Information about 
the status of animal health was also given, including: diarrhea in calves, symptoms of respiratory diseases in calves/heifers, abortions, and fetopathies. The percentage of cows with clinical mastitis (which occurred in the last two months before this study) was recorded, along with data on the number of somatic cells in the milk. The persons responsible for the herds were consulted on what they considered to be the main causes of slaughtered animals in the herd, as well as fertility problems, mastitis, lameness, and information about prophylaxis against BVDV carried out in herds and in the newly-purchased animals (those purchased within the last year).

\subsection{Statistical Analysis}

Numerical variables were presented as the median and interquartile range (IQR), and categorical variables were presented as the counts and percentages of herds with respect to each category. Between-group comparisons of nominal and ordinal variables were performed with the Pearson's chi-square test and the Mann-Whitney U test, respectively. Ninety five percent confidence intervals (CI 95\%) for proportions were calculated using the Wilson score method. All statistical tests were two-sided. A significance level $(\alpha)$ was set at 0.05 . Analysis was performed in TIBCO Statistica 13.3 (TIBCO Software Inc., Palo Alto, CA, USA). Bar charts were prepared in Microsoft Office Excel@.

\subsection{Ethics Statement}

The BTM used in this study originally came from the samples used as a material for a routine diagnostic of the health status of dairy cattle herds. The research outline was submitted to the II Local Ethics Committee for Animal Experiments in Wroclaw. Due to the non-invasive procedure of the samples collection, the Ethics Committee qualified the study as research that did not require ethics committee approval.

\section{Results}

The study was conducted in 354 dairy cattle herds, with herd size ranging from 30 to 831 heads of cattle. The presence of antibodies against BVDV were found in 118 herds, giving the herd-level seroprevalence of BVDV in Poland of 33.3\% (CI 95\%: 28.6\%, 38.4\%). Table 1 shows the number and percentage of positive herds in relation to the relative amount of antibodies, which were expressed as $\mathrm{s} / \mathrm{p}$.

Table 1. Presence of antibodies against the bovine viral diarrhea virus (BVDV) in examined dairy cattle herds, including the number and percentage of positive herds as well as the relative value of specific antibodies (s/p).

\begin{tabular}{cccc}
\hline S/P value & Number of BTM Samples (n) & \multicolumn{2}{c}{ Results (\%) } \\
\hline val $\leq 20 \%$ & 236 & 66.7 & negative \\
$20 \%<$ val $\leq 40 \%$ & 36 & 10.2 & positive \\
$40 \%<$ val $\leq 60 \%$ & 38 & 10.7 & positive \\
$60 \%<$ val $\leq 80 \%$ & 28 & 7.9 & positive \\
$80 \%<$ val $\leq 100 \%$ & 13 & 3.7 & positive \\
$100 \%<$ val & 3 & 0.8 & positive \\
Total & 354 & 100 & - \\
\hline
\end{tabular}

A high percentage (46.2\%) of seropositive herds was detected in the $(\mathrm{N})$ region, which is characterized by a high concentration of cattle counted per 100 ha of agricultural area. In this region, a typical feature is a large number of the relatively small herds, which restricts access to the pastures. However, the grazing of animals in small herds leads to more frequent contact with infected animals as well as contaminated surfaces/equipment. Additionally, the feeding method, which is closely related to the transport and distribution of the feed given to the animals, differed among the (N), (C), and $(\mathrm{N}-\mathrm{W})$ regions. This phenomenon is reflected in the proportion of grass grazed in the diet. 
An interesting observation of our study was that a greater frequency of BVDV infection was detected in herds where the owners had not purchased animals in the last year. Animals were introduced into stocks in the years 1995-2005 as a commonly used strategy to maintain the genetic quality of livestock, including milk yields in this period of time [17]. Additionally, the low percentage of seropositive herds in the (N-W) region, where vaccinations were not implemented, was correlated to the period before 2010, in which the animals were intensively purchased. Most of the cattle herds in this region were eliminated or they introduced BVDV eradication by vaccinating animals and removing PIs. However these herds were excluded from our study. An analysis of BVDV in the selected geographical regions of Poland is shown in Table 2.

Table 2. Distribution of BVDV-positive herds in geographical regions of Poland.

\begin{tabular}{|c|c|c|c|c|c|}
\hline Region & Voivodship & $\begin{array}{l}\text { No of Herds } \\
\text { (n) }\end{array}$ & $\begin{array}{l}\text { No of Positive } \\
\text { Herds (n) }\end{array}$ & $\begin{array}{c}\text { Herd-level } \\
\text { Seroprevalence (\%) }\end{array}$ & CI $95 \%$ \\
\hline $\mathrm{C}$ & $\begin{array}{l}\text { Mazovia }(\mathrm{n}=21) \\
\text { Łódź }(\mathrm{n}=20)\end{array}$ & 41 & 16 & 39.0 & $25.7 \%, 54.3 \%$ \\
\hline S & $\begin{array}{l}\text { Lower Silesia }(n=17) \\
\text { Opole }(n=27) \\
\text { Silesia }(n=12) \\
\text { Lesser Poland }(n=3)\end{array}$ & 59 & 20 & 33.9 & $23.1 \%, 46.6 \%$ \\
\hline $\mathrm{N}-\mathrm{W}$ & $\begin{array}{l}\text { Greater Poland }(n=93) \\
\text { Lubsz }(n=3) \\
\text { West-Pomerania }(n=2)\end{array}$ & 98 & 15 & 15.3 & $9.5 \%, 46.6 \%$ \\
\hline $\mathrm{N}$ & $\begin{array}{l}\text { Warmia-Masuria }(\mathrm{n}=33) \\
\text { Kuyavia-Pomerania }(\mathrm{n}=54) \\
\text { Pomerania }(\mathrm{n}=6)\end{array}$ & 93 & 43 & 46.2 & $36.5 \%, 56.3 \%$ \\
\hline $\mathrm{E}$ & $\begin{array}{c}\text { Holy Cross Province }(\mathrm{n}=2) \\
\text { Subcarpathia }(\mathrm{n}=5) \\
\text { Lublin }(\mathrm{n}=4) \\
\text { Podlaskie }(\mathrm{n}=52)\end{array}$ & 63 & 24 & 38.1 & $27.1 \%, 50.4 \%$ \\
\hline Total & & 354 & 118 & $33.3 \%$ & $28.6 \%, 38.4 \%$ \\
\hline
\end{tabular}

The statistical significance of the selected parameters considered to be a "risk" associated with BVDV infection is shown in Table 3. Only geographical location, access to pasture, and the purchases of new animals were statistically significant. All other analyzed parameters were not, including the presence of BVDV within herds.

Data regarding on the productivity of tested herds (Table 4) shows that the selected parameters were not statistically significant or of direct importance for maintaining BVDV within herds. Thus, it can suggest that the long-term presence of infections might cause the specific "homeostasis" within herds, leading to BVDV infection being less noticeable to owners. Clear differences were only detected for the length of the period between calving $(p=0.009)$. 
Table 3. Estimation of the factors considered to be a "risk" for the presence of BVDV at the herd level.

\begin{tabular}{|c|c|c|c|}
\hline Risk Factor & Category & $\begin{array}{c}\text { n (\%) of BVDV-Positive } \\
\text { Herds in a Category }\end{array}$ & $p$-Value \\
\hline \multirow{5}{*}{ Region of Poland } & $\mathrm{C}$ & $16 / 41(39.0)$ & \multirow{5}{*}{0.001} \\
\hline & $S$ & $20 / 59$ (33.9) & \\
\hline & $\mathrm{N}-\mathrm{W}$ & 15/98 (15.3) & \\
\hline & $\mathrm{N}$ & $43 / 93(46.2)$ & \\
\hline & E & $24 / 63(38.1)$ & \\
\hline $\begin{array}{c}\text { Average no of cows per } \\
100 \mathrm{ha}\end{array}$ & $\begin{array}{r}\text { BVI } \\
\text { (IQR f } \\
\text { BVI } \\
(I Q R f\end{array}$ & $\begin{array}{l}\text { ve: median of } 17 \\
\text { to } 21.5) \text { cows } / 100 \text { ha } \\
\text { ive: } \text { median of } 17 \\
\text { to } 19.7) \text { cows/100ha }\end{array}$ & 0.294 \\
\hline & $\leq 50$ & $22 / 44(50.0)$ & \multirow{5}{*}{0.506} \\
\hline & $51-100$ & $44 / 162(27.2)$ & \\
\hline \multirow{3}{*}{ Herd size $(\mathrm{n}=354)$} & $101-150$ & $24 / 70(34.3)$ & \\
\hline & $151-200$ & $21 / 39(53.9)$ & \\
\hline & $>200$ & $7 / 39(17.9)$ & \\
\hline \multirow{4}{*}{$\begin{array}{l}\text { Number of cows in } \\
\text { lactation }(n=349)\end{array}$} & $\leq 50$ & 67/214 (31.3) & \multirow{4}{*}{0.822} \\
\hline & $51-100$ & 39/99 (39.4) & \\
\hline & $>100$ & $8 / 36(22.2)$ & \\
\hline & $\leq 5.0$ & $5 / 11(45.5)$ & \\
\hline \multirow[t]{2}{*}{ Milk yield $(\mathrm{n}=334)$} & $5.1-8.0$ & $57 / 196(29.1)$ & \multirow[t]{2}{*}{0.31} \\
\hline & $>8.0$ & 47/127 (37.0) & \\
\hline \multirow{3}{*}{ Pasture $(\mathrm{n}=354)$} & Yes & $35 / 143(24.5)$ & \multirow{3}{*}{0.004} \\
\hline & No & $83 / 211(39.3)$ & \\
\hline & Calves & $8 / 77(10.4 \%)$ & \\
\hline \multirow[t]{2}{*}{ Animals grazed $(n=143)$} & Cows & $16 / 36(44.4 \%)$ & \multirow[t]{2}{*}{$<0.001$} \\
\hline & Both & $11 / 30(36.7 \%)$ & \\
\hline \multirow{2}{*}{$\begin{array}{l}\text { Purchase of animals for } \\
\text { replacement }(n=354)\end{array}$} & Yes & $46 / 176(26.1)$ & \multirow{2}{*}{0.004} \\
\hline & No & $72 / 178(40.5)$ & \\
\hline
\end{tabular}

Table 4. Production and clinical outcomes potentially linked to the BVD infection at the herd level.

\begin{tabular}{|c|c|c|c|}
\hline Clinical Manifestation (n) & Category & $\begin{array}{c}\text { n }(\%) \text { of BVDV-Positive } \\
\text { Herds in a Category }\end{array}$ & $p$-Value \\
\hline \multirow{4}{*}{ First calving [month of life] $(\mathrm{n}=354)$} & $<24$ & $9 / 22(40.9)$ & \multirow{3}{*}{0.814} \\
\hline & $24-30$ & $103 / 317(32.5)$ & \\
\hline & $>30$ & $6 / 15(40.0)$ & \\
\hline & $<2.4$ & $14 / 42(33.3)$ & \multirow{5}{*}{0.949} \\
\hline \multirow{4}{*}{ Average no of lactations per a cow $(n=328)$} & $2.5-2.9$ & $27 / 83(32.5)$ & \\
\hline & $3.0-3.4$ & $23 / 85(27.1)$ & \\
\hline & $3.5-3.9$ & 39/118 (33.1) & \\
\hline & $<380$ & $15 / 40(37.5)$ & \\
\hline \multirow{3}{*}{ Period between calving [days] $(\mathrm{n}=354)$} & $381-400$ & $62 / 160(38.7)$ & \multirow{3}{*}{0.009} \\
\hline & $401-420$ & $35 / 111(31.5)$ & \\
\hline & $>420$ & $6 / 43(14.0)$ & \\
\hline \multirow{2}{*}{ Foetopathy $(\mathrm{n}=354)$} & Yes & $10 / 30(33.3)$ & \multirow{2}{*}{0.999} \\
\hline & No & $108 / 324(33.3)$ & \\
\hline \multirow{2}{*}{ Diarrhoea $(n=354)$} & Yes & $44 / 114(38.6)$ & \multirow{2}{*}{0.148} \\
\hline & No & $74 / 240(30.8)$ & \\
\hline \multirow{2}{*}{ Abortion $(\mathrm{n}=354)$} & Yes & $48 / 138(34.8)$ & \multirow{2}{*}{0.643} \\
\hline & No & $70 / 216(32.4)$ & \\
\hline \multirow{5}{*}{ Problems with conception $(n=333)$} & very rare & $23 / 44(52.3)$ & \multirow{5}{*}{0.301} \\
\hline & rare & $18 / 48(37.5)$ & \\
\hline & moderately & 20/97 (20.6) & \\
\hline & often & $20 / 76(26.3)$ & \\
\hline & very often & $27 / 68(39.7)$ & \\
\hline \multirow{2}{*}{ Respiratory problems $(\mathrm{n}=354)$} & Yes & $41 / 133(30.8)$ & \multirow{2}{*}{0.438} \\
\hline & No & $77 / 221(34.8)$ & \\
\hline \multirow{5}{*}{ Mastitis ( $\mathrm{n}=326)$} & very rare & $20 / 49(40.8)$ & \multirow{5}{*}{0.34} \\
\hline & rare & $22 / 119(18.5)$ & \\
\hline & moderately & 31/71 (43.7) & \\
\hline & often & $13 / 47(27.7)$ & \\
\hline & very often & $15 / 40(37.5)$ & \\
\hline
\end{tabular}


Table 4. Cont.

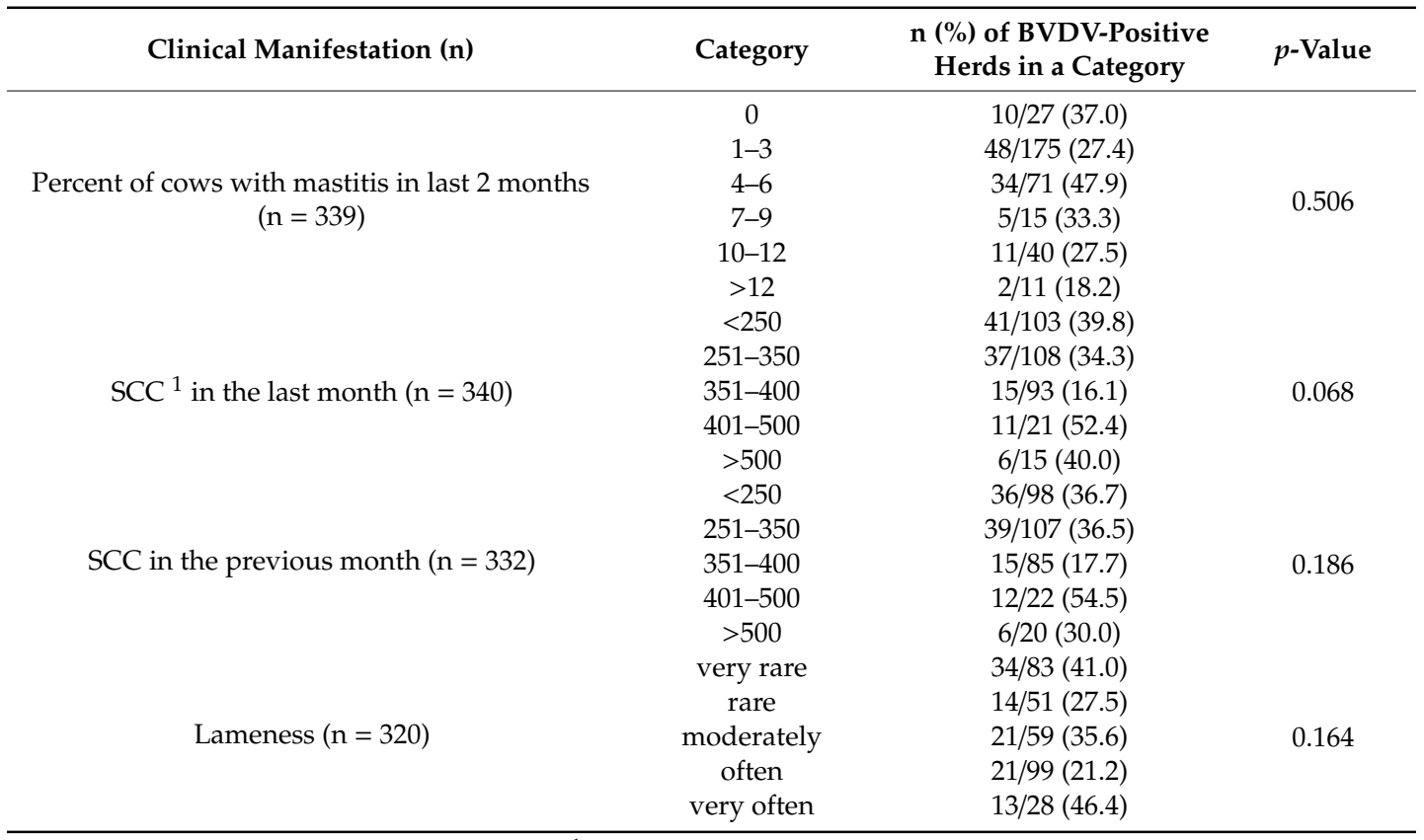

${ }^{1}$ Somatic Cell Counts.

\section{Discussion}

The circulation of BVDV in cattle herds causes acute, subclinical, and persistent infections in animals. All three of the forms causing the described forms of infection generate health problems in animals and lead to the presence of persistently or temporarily infected animals [18]. This, phenomenon facilitates the circulation of the virus in the cattle population, regardless of the presence of BVDV antibodies in high level $[19,20]$.

The presence of antibodies specific to BVDV is the first method used to detect the presence of PI animals and is the first step for diagnoses of the herds and controlling the spread of this virus in the region without the use vaccination [21,22]. Subsequently, other methods are used to confirm this, and the pursuit of further studies is used to identify this and to remove such infected animals as soon as possible [23]. It is important for control BVDV because this infection is considered to be distributed worldwide in farm animals, and evidence for the natural susceptibility of wildlife species $[24,25]$ comes mainly from serological surveys.

Differences in BVDV prevalence among regions or the introduction of the virus into the herds previously free of BVDV are often associated with particular epidemiological determinants, including the density of cattle populations, the condition and age of the animals, animal trade, and pasturing practices [26]. This relationship was observed in Poland, where the seroprevalence in bulls at artificial insemination centers was $0.9 \%$ [27], whereas in eastern and south-eastern regions of Poland the seroprevalence was 3.85\% in young calves between 6 and 12 months old [28]. On the other hand, the herd-level seroprevalence was 70.7\% in herds in eighteen provinces in Poland. High levels of antibodies (COD values above 0.55 ) were found in $52.8 \%$ of positive herds [29]. There is not much information about the BVDV situation in the neighboring countries. In Estonia, approximately $70 \%$ of all dairy cows were investigated. The BVDV infection status was established in 315-350 herds during three sampling periods: 1993-1995, 1997-1998, 1999-2000. The prevalence of $46 \%, 16 \%$, and $18 \%$ (respectively) for suspect PI herds was observed [30]. Specific BVDV-antibodies were detected in 713 of 1059 (67.3\%) analyzed samples from cattle farms in Eastern Ukraine [31]. In Slovakia, the prevalence of BVDV was $69 \%$ in cattle between 6 and 12 months of age [32]. In Lower Saxony, in 1996, the seroprevalence was $45.3 \%$ in cattle up to 3 years of age [33], whereas in Bavaria, in 2013, 
about $78 \%$ of investigated cattle herds showed antibodies against BVDV [34]. In Lithuania, 29.9\% of the herds were not infected with BVDV, and in $32.7 \%$ of the herds, between $70 \%$ and $100 \%$ of cattle were seropositive to BVDV in 1997-2001 [35]. The true prevalence of the basis of the criteria, such as BVDV-specific antibodies and antigens, based on various criteria in a cross-sectional study of 773 Belgian herds, was $47.4 \%$ and $4.4 \%$, respectively. Overall, $83.4 \%$ of the farmers stated that typical problems associated with BVDV were absent [36]. Moreover, only $8.4 \%$ of all farmers who completed the questionnaire reported problems possibly related to BVDV in the previous three years. Large herds were significantly more likely to be BVDV seropositive $(\mathrm{OR}=1.004 ; p<0.01)$. In non-vaccinated herds, the detection of PI animals was significantly associated with BVDV seropositivity $(\mathrm{OR}=13.8$; $p<0.01)$. Herds that had BVDV-related problems in the previous three years were more likely to be BVDV seropositive $(\mathrm{OR}=1.9 ; p<0.05)$. This phenomenon only became non-significant $(\mathrm{OR}=1.8$; $p=0.08$ ) when taking only a subset of herds that had not been vaccinating animals $<12$ months. The results of the present study have confirmed an active circulation of BVDV in a considerable number of Belgian cattle herds [36]. In the Asturias region of Spain, another region of Europe, seropositivity was $21 \%$, and, at the same time, no PI animals were detected, however, the authors detected two major factors associated with seropositivity: age and cow origin. These studies indicate that BVDV infection could be controlled in the selected area by controlling livestock-trade (without vaccines) [37].

Several studies have evaluated the presence of BVDV infection in cattle at the individual and herd levels following the implementation of the eradication programs, which were assessed several times [38]. The analysis of potential risk factors was evaluated to identify which risks were associated with the appearance of virus-positive newborn calves in herds, where BVDV had not been previously detected. The identification of such "risk" factors would facilitate a targeted approach in the future. The evaluated factors included: herd size, early death rate (i.e., the number of animals that either die before 15 days of age or were stillborn per number of new born calves each per year), buying in stock, using communal summer grazing, production type, age structure, and management strategy [22]. In Scotland dairy farms noted the highest concentration of antibodies with a prevalence of $73 \%$ at the herd level [39]. Risk factor analysis suggested that routine vaccination against BVDV, the suspicion of BVD, the housing of pregnant cows with calves, the total number of cows, and the proportion of cows that were dry were all associated with the presence of more of anti-BVDV antibodies in bulk tank milk. The inclusion of BVD within the health plan for cattle in farms was associated with a decline in BVDV antibody levels in the BTM. Denmark was at the greatest risk of BVDV and the prevalence being associated with was related to the import of live cattle (with a median of 5.0\%). Hoof trimming activity and the impact of animals imported from abroad represent the second most important introduction pathway (with a median of $2.4 \%$ ). The risk of BVDV introduction due to imported semen, embryos, and visiting trucks visits was $0.4 \%, 1.0 \%$, and $0.04 \%$, respectively [ 40$]$.

To identify the risk factors for BVDV infection in 300 randomly selected dairy herds in Brazil, BTM and indirect ELISA were used. Forty-three percent of herds were seropositive with artificial insemination and herd size being significantly associated with BVDV serological status $(p<0.05)$. The important risk factors were artificial insemination and an increasing number of visitors to the farm, who could introduce the BVDV virus through the contaminated clothes, shoes, and equipment [41]. In the cattle herds of Argentina, risk factors associated with BVDV included reproductive problems, such as outbreaks of abortions and calves with congenital defects. The BVDV appeared to be circulated via semen, resulting in PI infected animals becoming established. The average negative and positive rates of BVDV were $32.03 \%$ and $36.78 \%$, respectively. Variable importance analysis showed that the important predictors of BVDV occurrence were: (a) who inseminates the animals, (b) the number of neighbouring farms that have cattle, and (c) the routine performance of rectal palpation [42]. The circulation of BVDV within herds generates two important problems: the generation of PI animals and economic losses associated with decreases in the fertility and reproductive efficiency. Consequently, the inability of PI animals to overcome normal bovine pathogens could result in clinical presentations more closely linked to the secondary pathogens than to the BVDV infection [43]. Our previous 
study, which was performed on 270 cattle herds between 2007 and 2009, showed that $53.9 \%$ of cattle had antibodies to BVDV. An analysis of the clinical signs of bovine viral diarrhea (BVD) commonly observed in dairy cattle led to the conclusion that sudden drops in milk yield ( $\mathrm{OR}=2.037)$, diarrhea in calves $(\mathrm{OR}=1.422)$, and emaciation in juvenile ( $\mathrm{OR}=1.774)$ and adult animals $(\mathrm{OR}=1.715)$ were more frequent in infected herds compared to uninfected herds. No other clinical signs considered as typical for infected herds increased, including spontaneous abortions and fetopathies, nor were any respiratory and/or alimentary tract disorders noted [17]. Luzzago et al. [44], in the northern Italy, classified dairy herds according BVDV serological status and the risk levels for factors related to the within-herd spread of BVDV introduction, such as: through livestock trade, the attendance of animals at shows/exhibitions, a common grazing pasture, the within-herd spread of BVDV, and the results of initial serological testing. The calculated odds ratios were significant for all categories, except for livestock trade. Thus, screening tests, the questionnaires, and the related risk assessments proved a practical approach for predicting the BVDV status of cattle herds.

The estimates of economic losses due to BVDV infection vary depending on the immunity status of a given population and the pathogenicity of the virus strains. The introduction of the infection into a totally susceptible population invariably causes extensive losses in cattle populations until a state of equilibrium is reached [21]. Infection with highly virulent BVDV strains, which cause severe clinical signs and death after the acute course of the disease, gives rise to substantial economic losses [10,20].

Although the impact of BVDV in the herds are difficult to identify, regular vaccination with the elimination of PI animals and the identification of risk factors for this population is a regular feature of eradication programs. In turn, for countries that have eliminated BVDV from the population, determining risk factors is all the more important because the circulation control of this virus is based only on monitoring studies, hence determining risk groups and comparing them between countries is particularly important.

\section{Conclusions}

The current study demonstrates that the rate of BVDV infection was most strongly correlated with the geographical location of the examined cattle populations in Poland. The second most significant factor was considered to be the grazing of animals and linked access to the pasture. The purchasing of new animals to be introduced to herds was also statistically significant. Confirmed "risk" factors were similar or identical and were dependent on the size of the stock, management practices, and the implementation of the eradication programs.

Author Contributions: Conceptualization, K.R. and G.S.; methodology, G.S.; formal analysis, K.R.; investigation, K.P.-J. and S.S.; data curation, M.C.; writing—original draft preparation, K.R. and K.P.-J.; writing-review and editing, K.P.-J. and M.D.K.-B.; supervision, K.R.; project administration, K.R.; visualization, M.D.K.-B. All authors read and approved the final manuscript.

Funding: This research received no external funding.

Conflicts of Interest: The authors declare no conflict of interest.

\section{References}

1. Becher, P.; Thiel, H.J. Genus Pestivirus (Flaviviridae), Springer index of viruses, 2nd ed.; Tidona, C.A., Darai, G., Eds.; Springer Verlag: Heidelberg, Germany, 2011; pp. 483-488.

2. Simmonds, P.; Becher, P.; Bukh, J.; Gould, E.A.; Meyers, G.; Monath, T.; Muerhoff, S.; Pletnev, A.; Rico-Hesse, R.; Smith, D.B.; et al. ICTV Virus Taxonomy Profile. Flaviviridae. J. Gen Virol. 2017, 98, 2-3. [CrossRef]

3. Becher, P.; Avalos-Ramirez, R.; Orlich, M.; Cedillo-Rosales, S.; König, M.; Schweizer, M.; Stalder, H.; Schirrmeier, H.; Thiel, H.J. Genetic and antigenic characterization of novel pestivirus genotypes, implications for classification. Virology 2003, 311, 96-104. [CrossRef]

4. Yeşilbağ, K.; Alpay, G.; Becher, P. Variability and global distribution of subgenotypes of bovine viral diarrhea virus. Viruses 2017, 9, 128. [CrossRef] [PubMed] 
5. Vilcek, S.; Ridpath, J.F.; Van Campen, H.; Cavender, J.L.; Warge, J. Characterization of a novel pestivirus originating from a pronghorn antelope. Virus Res. 2005, 108, 187-193. [CrossRef] [PubMed]

6. Schirrmeier, H.; Strebelow, G.; Depner, K.; Hoffmann, B.; Beer, M. Genetic and antigenic characterization of an atypical pestivirus isolate. A putative member of a novel pestivirus species. J. Gen. Virol. 2004, 8512, 3647-3652. [CrossRef] [PubMed]

7. Ståhl, K.; Kampa, J.; Alenius, S.; Persson Wadman, A.; Baule, C.; Aiumlamai, S.; Belák, S. Natural infection of cattle with an atypical 'HoBi'-like pestivirus-implications for BVD control and for the safety of biological products. Vet Res. 2007, 38, 517-523. [CrossRef]

8. Ståhl, K.; Beer, M.; Schirrmeier, H.; Hoffmann, B.; Belák, S.; Alenius, S. Atypical 'HoBi'-like pestiviruses recent findings and implications thereof. Vet. Microbiol. 2010, 142, 90.

9. Decaro, N.; Lanave, G.; Lucente, M.S.; Mari, V.; Varello, K.; Losurdo, M.; Larocca, V.; Bozzetta, E.; Cavaliere, N.; Martella, V.; et al. Mucosal disease-like syndrome in a calf persistently infected by Hobi-like pestivirus. J. Clin. Microbiol. 2014, 52, 2946-2954. [CrossRef]

10. Houe, H. Epidemiological features and economical importance of bovine virus diarrhoea virus (BVDV) infections. Vet. Microbiol. 1999, 64, 89-107. [CrossRef]

11. Stott, A.W.; Humphry, R.W.; Gunn, G.J. Modelling the effects of previous infection and re-infection on the costs of bovine viral diarrhoea outbreaks in beef herds. Vet. J. 2010, 185, 138-143. [CrossRef]

12. Brownlie, J.; Clarke, M.C.; Howard, C.J.; Pocock, D.H. Pathogenesis and epidemiology of bovine virus diarrhoea virus infection of cattle. Ann. Rech. Vet. 1987, 18, 157-166. [PubMed]

13. Niskanen, R.; Lindberg, A.; Larsson, B.; Alenius, S. Lack of virus transmission from bovine viral diarrhoea virus infected calves to susceptible peers. Acta Vet. Scand. 2000, 41, 93-99.

14. Moen, A.; Sol, J.; Sampimon, O. Indication of transmission of BVDV in the absence of persistently infected (PI) animals. Prev. Vet. Med. 2005, 72, 93-98. [CrossRef] [PubMed]

15. Lindberg, A.L.E.; Alenius, S. Principles for eradication of bovine viral diarrhoea virus (BVDV) infections in cattle populations. Vet. Microbiol. 1999, 64, 197-222. [CrossRef]

16. Farm Animals in Poland; Central Statsitical Office: Warsaw, Poland, 2016; p. 76. (In Polish)

17. Rypuła, K.; Kumala, A.; Kaba, J.; Płoneczka-Janeczko, K.; Wojewoda-Kotwica, B.; Mazurkiewicz, M. Epidemiological aspects of BVD-MD infections in dairy cattle herds in Poland. Medycyna Wet. 2010, 66, 684-687.

18. Sørensen, J.T.; Enevoldsen, C.; Houe, H. A stochastic model for simulation of the economic consequences of bovine virus diarrhoea virus infection in a dairy herd. Prev. Vet. Med. 1995, 23, 215-227. [CrossRef]

19. Introduction and qualitative risk analysis. Handbook on Import Risk Analysis for Animals and Animals Products. OIE 2010, 1, 132-133.

20. Ridpath, J.F.; Falkenberg, S.M.; Bauermann, F.V.; VanderLey, B.L.; Do, Y.; Flores, E.F.; Rodman, D.M.; Neill, J.D. Comparison of acute infection of calves exposed to a high-virulence or low-virulence bovine viral diarrhea virus or a HoBi-like virus. Am. J. Vet. Res. 2013, 74, 438-442. [CrossRef]

21. Bachofen, C.; Stalder, H.; Vogt, H.R.; Wegmüller, M.; Schweizer, M.; Zanoni, R.; Peterhans, E. Bovine viral diarrhea (BVD): From biology to control. Berl. München Tierärztl Wochenschr 2013, 126, 445-461.

22. Presi, P.; Struchen, R.; Knight-Jones, T.; Scholl, S.; Heim, D. Bovine viral diarrhea (BVD) eradication in Switzerland-experiences of the first two years. Prev. Vet. Med. 2011, 99, 112-121. [CrossRef]

23. Garoussi, M.T.; Mehrzad, J.; Nejati, A. Investigation of persistent infection of bovine viral diarrhea virus (BVDV) in Holstein dairy cows. Trop. Anim. Health. Prod. 2019, 51, 853-858. [CrossRef]

24. Passler, T.; Walz, P.H. Bovine viral diarrhea virus infections in heterologous species. Anim. Health Res. Rev. 2010, 11, 191-205. [CrossRef] [PubMed]

25. Ridpath, J.F.; Neill, J.D. Challenges in identifying and determining the impacts of infection with pestiviruses on the herd health of free ranging cervid populations. Front. Microbiol. 2016, 7, 921. [CrossRef] [PubMed]

26. Santman-Berends, I.M.G.A.; Mars, M.H.; Van Duijn, L.; Van den Broek, K.W.H.; Van Schaik, G. A quantitative risk-analysis for introduction of Bovine Viral Diarrhoea Virus in the Netherlands through cattle imports. Prev. Vet. Med. 2017, 1, 103-113. [CrossRef] [PubMed]

27. Polak, M.P.; Zmudzinski, J.F. Prevalence of bovine viral diarrhea virus infection in bulls in artificial insemination centers in Poland. Vet. Microbiol. 1999, 64, 253-257. [CrossRef] 
28. Wernicki, A.; Urban-Chmiel, R.; Stegierska, D.; Adaszek, L.; Kalinowski, M.; Puchalski, A.; Dec, M. Detection of the bovine viral diarrhoea virus (BVDV) in young beef cattle in eastern and south-eastern regions of Poland. Pol. J. Vet. Sci. 2015, 18, 141-146. [CrossRef]

29. Kuta, A.; Polak, M.P.; Larska, M.; Żmudziński, J.F. Monitoring of bovine viral diarrhoea virus (BVDV) infection in polish dairy herds using bulk tank milk samples. Bull Vet. Inst. Pulawy 2013, 57, 149-156. [CrossRef]

30. Viltrop, A.; Alaots, J.; Pärn, M.; Must, K. Natural Changes in the Spread of Bovine Viral Diarrhoea Virus (BVDV) Among Estonian Cattle. J. Vet. Med. Series B 2002, 49, 263-269. [CrossRef]

31. Stegniy, B.T.; Gerilovych, A.P.; Vilcek, S.; Peterhans, E.; Kucheriavenko, R.O.; Stegniy, M.Y.; Goraichuk, I.V.; Bolotin, V.I.; Solodiankin, O.S. Molecular Epidemiology Issues of BVDV Infection in the Eastern Ukraine. Agricult. Sci. Pract. 2014, 1, 37-41. [CrossRef]

32. Vilcek, S.; Mojzisova, J.V.B.; Paulik, S.; Strojny, L.; Durkovic, B.; Hipokova, V. A survey for BVDV antibodies in cattle farms in Slovakia and genetic typing of BVDV isolates from imported animals. Acta Vet. Hung. 2003, 51, 229-236. [CrossRef]

33. Frey, H.R.; Flebbe, U.; Liess, B. Prävalenz und klinische Symptomatik persistenter BVD-virusinfektionen in Rinderbeständen Niedersachsens. Der Praktische Tierarzt 1996, 77, 49-52. (In Germany)

34. BVD/MD: Erste Grundlagen für landesweites Programm zur Bekämpfung der Infektionskrankheit; Bayerisches Landesamt für Gesundheit und Lebensmittelsicherheit (LGL): Oberschleißheim, Germany, 2013; pp. $22-25$. (In Germany)

35. Mockeliūniene, V.; Salomskas, A.; Mockeliūnas, R.; Petkevicius, S. Prevalence and epidemiological features of bovine viral diarrhoea virus infection in Lithuania. Vet. Microbiol. 2004, 99, 51-57. [CrossRef] [PubMed]

36. Sarrazin, S.; Veldhuis, A.; Méroc, E.; Vangeel, I.; Laureyns, J.; Dewulf, J.; Caij, A.B.; Piepers, S.; Hooyberghs, J.; Ribbens, S.; et al. Serological and virological BVDV prevalence and risk factor analysis for herds to be BVDV seropositive in Belgian cattle herds. Prev. Vet. Med. 2013, 108, 28-37. [CrossRef] [PubMed]

37. Mainar-Jaime, R.C.; Berzal-Herranz, B.; Arias, P.; Rojo-Vázquez, F.A. Epidemiological pattern and risk factors associated with bovine viral-diarrhoea virus (BVDV) infection in a non-vaccinated dairy-cattle population from the Asturias region of Spain. Prev. Vet. Med. 2001, 52, 63-73. [CrossRef]

38. Givens, M.D.; Newcomer, B.W. Perspective on BVDV control programs. Anim. Health Res. Rev. 2015, 16, 78-82. [CrossRef] [PubMed]

39. Humphry, R.W.; Brülisauer, F.; McKendrick, I.J.; Nettleton, P.F.; Gunn, G.J. Prevalence of antibodies to bovine viral diarrhoea virus in bulk tank milk and associated risk factors in Scottish dairy herds. Vet. Rec. 2012, 171, 445. [CrossRef]

40. Foddai, A.; Boklund, A.; Stockmarr, A.; Krogh, K.; Enøe, C. Quantitative assessment of the risk of introduction of bovine viral diarrhea virus in Danish dairy herds. Prev. Vet. Med. 2014, 116, 75-88. [CrossRef]

41. Almeida, L.L.; Miranda, I.C.; Hein, H.E.; Neto, W.S.; Costa, E.F.; Marks, F.S.; Rodenbusch, C.R.; Canal, C.W.; Corbellini, L.G. Herd-level risk factors for bovine viral diarrhea virus infection in dairy herds from Southern Brazil. Res. Vet. Sci. 2013, 95, 901-907. [CrossRef]

42. Altamiranda, E.A.; Kaiser, G.G.; Weber, N.; Leunda, M.R.; Pecora, A.; Malacari, D.A.; Morán, O.; Campero, C.M.; Odeón, A.C. Clinical and reproduction consequencs of using BVDV-contaminated semen in artificial insemination in a beef herd in Argentina. Anim. Reprod. Sci. 2012, 133, 146-152. [CrossRef]

43. Tajima, M.; Dubovi, E.J. Genetic and clinical analyses of bovine viral diarrhea virus isolates from dairy operations in the United States of America. J. Vet. Diagn. Investig. 2005, 17, 10-15. [CrossRef]

44. Luzzago, C.; Frigerio, M.; Piccinini, R.; Daprà, V.; Zecconi, A. A scoring system for risk assessment of the introduction and spread of bovine viral diarrhoea virus in dairy herds in Northern Italy. Vet. J. 2008, 177, 236-241. [CrossRef] [PubMed]

(C) 2020 by the authors. Licensee MDPI, Basel, Switzerland. This article is an open access article distributed under the terms and conditions of the Creative Commons Attribution (CC BY) license (http://creativecommons.org/licenses/by/4.0/). 